\title{
MANAJEMEN KEPALA SEKOLAH DALAM MENANAMKAN BUDAYA ISLAMI MELALUI PENDIDIKAN MODEL FULL DAY SCHOOL STUDI KASUS DI SD ISLAM NABAWI KEDUNGADEM
}

\author{
Angga Prastiyo1), Nadia Arifia2) \\ Institut Pesantren Sunan Drajat Lamongan, Indonesia \\ Email: anggaprastiyo@gmail.com ${ }^{1}$, nadiaarifia@gmail.com²
}

Dikirim: 15 April 2021 Direvisi: 20 Juni 2021 Direvisi: 31Juli 2021

\begin{abstract}
Abstrak: Pendidikan bersifat mutlak dalam kehidupan, baik dalam kehidupan seseorang dan keluarga, maupun dalam kehidupan berbangsa dan bernegara. Sehingga kehidupan sangat penting dan tidak dapat dipisahkan dengan kehidupan, karena kemajuan suatu bangsa dan negara banyak ditentukan oleh kemajuan pendidikan bangsa atau negara tersebut. Mengingat sangat pentingnya dalam kehidupan, sehingga pendidikan harus dilaksanakan. sebaik-baiknya agar memperoleh hasil yang sesuai dengan apa yang diharapkan. Penanaman budaya Islami merupakan salah satu kebijakan yang harus diperhatikan oleh sekolah umumnya atau lembaga pendidikan Islam khususnya. Dengan adanya budaya Islami di sekolah atau lembaga pendidikan Islam dapat mengenalkan dan menanamkan nilai-nilai agama Islam sehingga pada proses perkembangan anak nantinya senantiasa berpegang teguh terhadap nilai-nilai ajaran agama Islam dan dapat membentuk akhlaqul karimah peserta didik, selain itu dapat mewujudkan nilai-nilai ajaran agama sebagai suatu tradisi yang harus diterapkan oleh lembaga pendidikan Islam Kepala sekolah yang mampu mengembangkan budaya Islami di sekolah, yakni dengan menggunakan strategi yang dimiliki untuk mengembangkan budaya Islami di sekolah dengan menggunakan pendidikan model full day school.
\end{abstract}

Kata Kunci : : Manajemen Kepala Sekolah; Budaya Islami term2; Pendidikan Model Full Day School

\begin{abstract}
Education is absolute in life, both in the life of a person and family, as well as in the life of the nation and state. So that life is very important and cannot be separated from life, because the progress of a nation and state is largely determined by the educational progress of the nation or country. Given the very importance in life, so education must be implemented. in order to obtain the desired result. The cultivation of Islamic culture is one of the policies that must be considered by schools in general or Islamic educational institutions in particular. With the existence of Islamic culture in schools or Islamic educational institutions can introduce and instill Islamic religious values so that in the process of child development later they will always hold fast to the values of Islamic teachings and can form the moral character of students, besides that they can realize the values of Islam. religious teachings as a tradition that must be applied by Islamic educational institutions. Principals who are able to develop Islamic culture in schools, namely by using the strategies they have to develop Islamic culture in schools by using full day school education models

Keywords : Principal Management; Islamic culture term2; Full Day School Model Education
\end{abstract}

Setiap lembaga pendidikan diharapkan memiliki suatu kelebihan yang bersifat positif, misalnya berupa budaya yang di berdayakan lembaga untuk menjadi pembeda lembaga pendidikan tersebut dengan lembaga pendidikan yang lain. Sehingga lembaga tersebut memiliki keunikan/keunggulan yang dijanjikan kepada masyarakat sebagai konsumen pendidikan. Oleh karena itu, agar kualitas pendidikan meningkat, selain dilakukan secara struktural perlu diiringi pula dengan pendekatan kultural. 
Berdasarkan deskripsi tersebut, maka beberapa pemimpin dalam bidang pendidikan memberikan arah baru, bahwa culture atau budaya unitunit pelaksana kegiatan yang ada di sekolah turut menjadi salah satu faktor penentu dalam meningkatkan kualitas pendidikan yang berlangsung pada sebuah lembaga atau institusi pendidikan. ${ }^{1}$ Budaya Islam dalam konteks pendidikan adalah suatu usaha sadar dan terencana untuk mewujudkan lingkungan dan secara aktif mengembangkan potensi dirinya untuk memiliki kekuatan spiritual keagamaan yang berakar dari nilai-nilai agama dan mengamalkannya sebagai basis dasar kehidupan sehari-hari. ${ }^{2}$

Budaya adalah nilai, pemikiran serta simbol yang mempengaruhi perilaku, sikap, kepercayaan, serta kebiasaan seseorang dalam sebuah organisasi. Pola pembiasaan dalam sebuah budaya sebagai sebuah nilai yang diakuinya bisa membentuk sebuah pola prilaku. ${ }^{3}$

Penanaman budaya Islami merupakan salah satu kebijakan yang harus diperhatikan oleh sekolah umumnya atau lembaga pendidikan Islam khususnya. Dengan adanya budaya Islami di sekolah atau lembaga pendidikan Islam dapat mengenalkan dan menanamkan nilai-nilai agama Islam sehingga pada proses perkembangan anak nantinya senantiasa berpegang teguh terhadap nilai-nilai ajaran agama Islam dan dapat membentuk akhlaqul karimah peserta didik, selain itu dapat mewujudkan nilai-nilai ajaran agama sebagai suatu tradisi yang harus diterapkan oleh lembaga pendidikan Islam. Kepala sekolah yang mampu mengembangkan budaya Islami di sekolah, yakni dengan menggunakan strategi yang dimiliki untuk mengembangkan budaya Islami di sekolah, dapat dikatakan kepala sekolah tersebut telah berhasil untuk menjadi kepala sekolah yang berkualitas.

Berdasarkan pemaparan di atas bahwa penanaman budaya Islam di lembaga pendidikan sangatlah penting bagi perkembangan peserta didik dan juga ciri kas dari suatu lembaga pendidikan itu sendiri. Dengan adanya penanaman budaya Islam diharapkan mampu untuk mengenalkan dan menanamkan nilai-nilai norma agama Islam pada peserta didik agar paham dengan ajaran-ajaran Islam dan juga dapat menjadikan peserta didik memiliki budi pekerti yang baik (akhlakul karimah).

SD Islam Nabawi merupakan sekolah swasta yang bercorak Islami yang didirikan oleh bapak $\mathrm{H}$. SURYONO, S.E., M.M. pada tahun 2006 yang bertempat di desa Cemplo kecamatan Kedungadem kabupaten Bojonegoro. SD Islam Nabawi ini dalam pembelajarannya lebih menekankan kepada pembelajaran nilai-nilai Islami. Corak Islami yang menjadi ciri khas sekolah ini menjadikan agama Islam sebagai pegangan utama dalam proses pendidikan dan pengajarannya menjadikan sekolah ini mempunyai daya tarik tersendiri bagi masyarakat sekitar. SD Islam Nabawi dalam pembelajarannya memakai pendidikan model Full Day School yang mana pembelajaran ini digunakan untuk memaksimalkan dalam menanamkan budaya Islami kepada anak didik, sehingga pada proses perkembangan anak nantinya bisa berpegang teguh terhadap nilai-nilai ajaran agama Islam dan bisa mengamalkannya, dan juga nantinya anak didik mempunyai budi pekerti yang baik (berakhlaqul karimah).

Dalam penanaman budaya Islami di SD Islam Nabawi ini, kepala sekolah mempunyai peran yang sangat vital dalam menanamkan budaya Islami pada anak didik. Dalam memanajemen penanaman budaya Islami, kepala sekolah memberikan berbagai program tentang budaya Islami, di antaranya ialah pembiasaan $5 \mathrm{~S}$, Pelaksanaan Sholat Dhuha, pembiasaan hafalan Asmaul Husna dan hafalan surat-surat pendek sebelum pembelajaran dimulai, pembelajaaran Al-Islamiyya yang meliputi BTA (Baca Tulis AlQuran), Tauhid, Akidah Akhlaq, Fiqih, Hadits, Bahasa Arab, SKI dan pembelajaran Islami pada umumnya. Dan pembelajaran Dzibaiyyah, Istighotsah, Tahlil, dan kegiatan-kegiatan pada peringatan hari besar Islam.

Dalam sebuah manajemen yang digunakan oleh kepala sekolah dalam upaya penanaman budaya Islami di SD Islam Nabawi pastinya tidak luput dari faktor penghambat dan pendukung dalam pelaksanaannya. Faktor penghambat dalam penanaman budaya Islami yaitu dari siswa yang kurang serius dalam pembelajaran maupun pembiasaan dalam melakukan budaya Islami, seperti saat pelaksanaan sholat berjamaah anak-anak masih belum sadar dan belum sungguh-sungguh dalam pelaksanaannya. Dan faktor pendukungnya adalah semua dewan guru sangat mendukung dan sangat antusias dalam mendampingi anak-anak dalam menanamkan budaya Islami dan juda fasilitas yang ada juga sangat mendukung dalam pelaksanaannya.

\footnotetext{
${ }^{1}$ Haryati Diyati, "Peran Kepala Sekolah Dalam Mengembangkan Budaya Sekolah”, (Tesis, Pasca Sarjana Fakultas Ilmu Pendidikan Universitas Negeri Yogyakarta, Yogyakarta: 2014), 3.

2 Muhaimin. Rekontruksi Pendidikan Islam dari Paradigma Pengembangan, Manajemen Kelembagaan, Kurikulum bingga Strategi Pembelajaran (Jakarta: PT Raja Grafindo Persada, 2009), 312.

${ }^{3}$ Rusmin Tumaggor, Kholis Ridho, Nurochim, Imu Sosial Dan Budaya Dasar, Ed. 1. Cet. 1 (Jakarta: Kencana, 2010$), 17$.
} 
Dalam wawancara penulis dengan salah satu guru yang mengajar di SD Islam Nabawi faktor-faktor yang mempengaruhi muculnya penanaman budaya Islami di lembaga tersebut yaitu: (1) Dari segi lingkungan daerah desa Kedungadem tempat SD Islam Nabawi berdiri masyarakatnya sangat minim sekali dengan pengetahuan ilmu agama, (2) Menanamkan budaya Islami kepada anak mulai usia dini sangatlah dianjurkan sekali, guna membentuk karakter yang mempunyai jiwa Islami dan bisa mengamalkan ajaran-ajaran Islam, (3) Sebagai ciri khas tersendiri bagi lemabaga SD Islam Nabawi, yang mana nanti bisa menjadi keunggulan tersendiri bagi lembaga SD Islam Nabawi. ${ }^{4}$

\section{Metode Penelitian}

\section{Pendekatan dan Jenis Penelitian}

Pada penelitian ini, peneliti menggunakan pendekatan penelitian kualitatif. dan jenis deskriptif ini penulis menggunakan pendekatan kualitatif karena permasalahan yang dibahas dimaksudkan untuk mendeskripsikan, menguraikan dan menggambarkan tentang pelaksanaan manajemen kepala sekolah dalam menanamkan budaya Islami melalui pendidikan model full day school di SD Islam Nabawi Kedungadem Bojonegoro.

\section{Deskripsi Latar Penelitian}

Dalam penelitian ini, penelitian ini lokasi yang digunakan di SD Islam Nabawi ini terletak di pedesaan dan termasuk juga dekat dengan pusat kecamatan maka dari itu peneliti tertarik untuk meneliti di sekolah tersebut dikarenakan sekolah itu termasuk sekolah yang banyak diminati oleh masyarakat karena terkenal dengan pembelajaran yang mengutamakan nilai-nilai Islami. SD Islam Nabawi mempunyai keunikan dan karakteteristik tersendiri, salah satunya yaitu sekolah SD Islam Nabawi sebagai sekolah yang menggunakan pembelajaran pendidikan model full day school yang mana di dalamnya ditanamkan pembelajaran pendidikan agama Islam yang mana nanti bisa menghasilkan lulusan yan mempunyai budi pekerti yang baik (akhlakul karimah pastinya) dan selalu mengamalkan nilai-nilai Islamia.

\section{Instrumen Penelitian}

Dalam penelitian kualitatif, yang menjadi instrumen atau alat penelitian adalah peneliti sendiri. Oleh karen itu peneliti sebagai instrumen juga harus "divalidasi” seberapa jauh peneliti kualitatif siap melakukan penelitian yang selanjutnya terjunlangsung ke lapangan. Validasi terhadap peneliti sebagai instrumen meliputi validasi terhadap pemahaman metode penelitian kualitatif, penguasaan wawasan terhadap bidang yang diteliti, kesiapan peneliti untuk memasuki objek penelitian, baik secara akademik maupun logistiknya. Yang melakukan validasi adalah peneliti sendiri, melalui evaluasi diri seberapa jauh pemahaman terhadap metode kualitatif, penguasaan teori dan wawasan terhadap bidang yang diteliti, serta kesiapan dan bekal memasuki lapangan.

\section{Data dan Sumber Data}

Sumber data adalah subjek dari mana data diperoleh. ${ }^{5}$ Yang juga dapat diartikan sember dari mana data tersebut diperoleh baik itu berbentuk kata- kata, tindakan maupun dokumentasi dan lain-lain. Dan untuk menyelesaikan masalah dalam penelitian ini, maka peneliti mencari data-data dari beberapa sumber yang berkaitan dengan manajemen kepala sekolah dalam menanamkan budaya islami melalui pendidikan model full day school studi kasus di sd islam nabawi kedungadem di antaranya mempersiapkan data primer sebagai data utama dan data sekunder sebagai data pendukung dalam penelitian ini.

\section{Data Primer}

Sumber langsung dikumpulkan oleh peneliti dari yang diminta informasi (informan). Adapun informan dalam penelitian ini adalah kepala sekolah, waka kurikulum, waka kesiswaan dan tenaga

\footnotetext{
${ }^{4}$ Fatkhul Alim, Wawancara, Bojonegoro, 12 Juli 2020. Pada 08.30-09.30 WIB.

${ }_{5}^{5}$ Suharsimi Arikunto, Prosedur Penelitian: Suatu Pendekatan Praktek (Jakarta: PT Rineka Cipta, 2002), 107.
} 
Angga Prastiyo, Nadia Arifia

pendidik di SD Islam Nabawi Kedungadem Bojonegoro ${ }^{6}$

Data Sekunder

Sumber yang tidak langsung memberikan data kepada pengumpul data, misalnya lewat orang lain atau lewat dokumen yaitu dalam hal ini data diperoleh dari dokumen-dokumen.

\section{Prosedur Pengumpulan Data}

\section{Observasi}

Penelitian kualitatif menggunakan metode pengumpulan data dengan observasi. Metode ini digunakan untuk mendapatkan data yang lebih lengkap dan mengetahui tingkat kemampuan yang tampak. Observasi atau pengamatan merupakan suatu teknik atau cara pengumpulan data dengan jalan mengadakan pengamatan terhadap kegiatan yang sedang berlangsung. ${ }^{7}$

\section{Interview (wawancara)}

Wawancara merupakan pertemuan dua orang untuk bertukar informasi dan ide melalui tanya jawab, sehingga dapat dikontruksikan makna dalam suatu topik tertentu.

\section{Dokumentasi}

Dukumen merupakan catatan peristiwa yang sudah berlalu. Dokumen bisa berbentuk tulisan, gambar atau karya karya monumeltal dari seseorang. Dokumen yang berbentuk tulisan misalnya catatan harian, sejarah kehidupan (life histories), cerita, bioggrafi, peraturan, kebijakan. Dokumen yang berbentuk gambar misalnya foto, gambar hidup, sketsa dan lain lain. Dokumen yang berbentuk karya misalnya karya seni yang dapat berupa gambar, patung, film, dan lain lain. Studi dokumen merupakan pelengkap dari penggunaan metode observasi dan wawancara dlam penelitian kualitatif. ${ }^{8}$

\section{Teknik Analisis Data}

Menurut Miles dan Hubirmen, kegiatan analisis kualitatif terdiri atas tiga alur kegiatan yang terjadi secara bersamaan, yaitu sebagai berikut:

\section{Data Reduction (Data Reduksi)}

Mereduksi data berarti merangkum, memilih hal hal yang pokok, memfokuskan pada hal hal yang penting, dicari tema dan polanya dan membuang yang tidak perlu. Dalam hal ini peneliti mengumpulkan data dengan cara merangkum, atau mengumpulkan data. Data reduksi yang diambil peneliti terkait manajemen kepala sekolah dalam menanamkan budaya Islami melalui pendidikan model full day school. Selanjutnya, dalam analisis data kualitatif, penyajian ata berarti sekumpulan informasi yang tersusun yang memberikan kemungkinan akan adanya penarikan kesimpulan dan pengambilan data tertentu.

\section{Data Display (Penyajian Data)}

Setelah data reduksi, maka langkah selanjutnya adalah mendisplay data. Melalui penyajian data tersebut, maka data terorganisasikan, tersusun dalam pola hubungan, sehingga akan semakin mudah difahami. Dalam hal ini peneliti menguraikan jawaban-jawaban yang diberikan kepala sekolah dan semua pihak yang terkait.

3. Verification atau penarikan kesimpulan

Dalam hal ini peneliti mengemukakan beberapa kesimpulan dari hasil wawancara. Penarikan kesimpulan dan verifikasi adalah kesimpulan awal yang dikemukakan masih bersifat sementara, dan akan berubah jika ditemukan bukti kuat dan mendukung pada tahap awal dan didukung oleh buktibukti yang valid dan konsisten saat peneliti turun ke lapangan mengumpulkan data, maka kesimpulan yang dikemukakan merupakan kesimpulan yang kredibel. ${ }^{9}$

\footnotetext{
${ }^{6}$ Sugiyono, Metode Penelitian Kuantitatif, Kualitatif, Dan R\&D (Bandung: alfabeta, 2017), 225.

${ }^{7}$ Nana Syaodah Sukamdinata, Metode Penelitian Pendidikan (Bandung: PT Remaja Rosdakarya, 2008), 220.

${ }^{8}$ Ibid., 240

${ }^{9}$ Sugiyono, Metode Penelitian.., 252.
} 


\section{Keabsahan Data}

Selain menganalisis data, peneliti juga harus menguji keabsahan data agar memperoleh data yang valid. Untuk menetapkan keabsahan data tersebut diperlukan teknik pemeriksaan. Uji keabsahan data dalam penelitian ini menggunakan uji kreadibilitas, uji kreadibilitas data atau kepercayaan terhadap data hasil penelitian dalam penelitian ini menggunakan teknik triangulasi.

Trianggulasi adalah teknik pemeriksaan keabsahan data yang memanfaatkan sesuatu yang lain diluar data itu untuk keperluan pengecekan atau sebagai pembanding terhadap data itu, tekniknya dengan pemeriksaan sumber lainnya ${ }^{10}$

Triangulasi dalam pengujian kreadibilitas ada tiga macam, yaitu sebagai berikut:

\section{Triangulasi Sumber}

Untuk menguji kreadibilitas data dilakuakan dengan cara mengecek data yang telah diperoleh melalui berbagai sumber. Mislanya data yang diperoleh dianalisis oleh peneliti sehingga menghasilkan suatu kesimpulan, yang mana selanjutnya dibandingkan atau dimintakan kesepakatan dengan sumber data yang lain apakah terjadi perubahan atau tidak dari kesimpulan awal tersebut.

2. Triangulasi Teknik

Untuk menguji kreadibilitas data dilakukan dengan mengecek data pada sumber yang sama tetapi dengan teknik yang berbeda. Misalnya mengecek data bisa melalui wawancara, observasi, dokumentasi. Bila dengan teknik pengujian kreadibilitas data tersebut menghasilakn data yang berbeda, maka peneliti melakukan diskusi lebih lanjut kepada sumber data yang bersangkutan untuk memastikan data memang dianggap benar

\section{Triangulasi Waktu}

Waktu juga sering mempengaruhi kreadibilitas data, untuk itu dalam angka pengujian kreadibilitas data dapat dilakukan dengan cara melakuakan pengecekan dengan wawancara, observasi, atau teknik lain dalam waktu dan situasi yang berbeda. Misalnya data yang dikumpulkan dengan teknik wawancara di pagi hari pada saat narasumber dalam keadaan masih segar, akan memberikan data yang lebih valid sehingga lebih kredibel. Selanjutnya dapat dilakukan pengecekkan dengan wawancara, observasi atau teknik lain dalam waktu/situasi yang berbeda. Bila hasil uji menghasilkan data yang berbeda, maka dilakukan secara berulang-ulang sehingga sampai ditemukan kepastian datanya

\section{Findings and Discussion}

\section{Manajemen Kepala Sekolah dalam menanamkan budaya Islami melalui pendidikan model} full day school di SD Islam Nabawi Kedungadem

Berdasarkan hasil penelitian yang telah dipaparkan dalam pembahasan manajemen kepala sekolah dalam menanamkan budaya Islami melalui pendidikan model full day school di SD Islam Nabawi Kedungadem yaitu meliputi penanaman budaya 5S (Salam, Senyum, Sapa, Sopan dan Santun), sholat dhuha, pembiasaan menghafalkan Asma'ul Husna dan Jur. 'Amma, berdoa bersama sebelum jam pelajaran dimulai, dan pendidikan Al-Islamiyyah di siang hari. Adapun pendidikan AlIslamiyyah itu sendiri meliputi mata pelajaran BTA (Baca Tulis Al- Quran), Akidah Akhlaq, Fiqih, Hadits, Bahasa Arab dan SKI. Dalam hal memanajemen H. Muhtarom selaku kepala sekolah melakukan 4 langkah yakni Perencanaan (Planing), Pengorganisasian (Organižng), Pelaksanaan (Actuating), dan Pengawasan (Controling).

a. Perencanaan (planing)

Kepala sekolah telah membuat suatu perencanaan yang sudah terjadwal tentang penyelenggaraan sistem pendidikan dan penanaman budaya Islami yang sesuai dengan visi dan misi sekolah. Kaitannya dengan penyusunan waktu belajar serta penanaman budaya Islami kepada

\footnotetext{
${ }^{10}$ Lexy J.Moeleng, Metodologi Penelitian Kualitatif (Bandung: PT Remaja Rosdakarya, 2014), 178.
} 
anak didik, yang meliputi penanaman 5S (Salam, Senyum, Sapa, Sopan dan Santun), pembiasaan sholat dhuha, hafalan Asmaul Husna dan Juг Amma, berdoa sebelum memulai pelajaran, sholat dhuhur berjamaah dan pendidikan Al-Islamiyyah. Hal ini sesuai dengan teori Fungsi perencanaan yaitu menentukan tujuan atau kerangka tindakan yang diperlukan umtuk mencapai tujuan tertentu. Perencanaan dilakukan dengan mengkaji kekuatan dan kelemahan organisasi, menentukan kesempatan dan ancaman serta menentukan strategi, kebijakan, taktik dan program. $^{11}$

b. Pengorganisasian (Organizing)

Kepala sekolah telah seoptimal mungkin dalam memberi tugas para bapak/ibu guru sesuai dengan keahlian mereka, dan tidak mau membebani mereka dengan merangkap tugas. Jadi dalam membagi tugas mengajar, kepala sekolah memberikan tugas atau tanggungjawab mengajar kepada bapak/ibu guru yang sudah ahli dalam bidangnya. Khususnya dalam pembelajaran Al-Islamiyyah kepala sekolah memilih guru yang rata-rata lulusan dari pesantren untuk mengajar pendidikan $\mathrm{Al}$ Islamiyyah.

Hal ini sesuai dengan teori Pengorganisasian adalah proses pembagian kerja ke dalam tugastugas yang lebih kecil, membebankan tugas-tugas itu kepada orang yang sesuai dengan kemampuannya, mengalokasikan sumber daya, dan mengkoordinasikannya demi efektifitas pencapaian tujuan organisasi. ${ }^{12}$

c. Pelaksanaan (Actuating)

Dalam hal ini kepala sekolah sudah menuangkan jadwal yang harus dijalankan oleh bapak/ibu guru mengenai proses pembelajaran di sekolah mulai dari awal masuk sekolah sampai pelajaran sekolah selesai. Tidak hanya itu kepala sekolah juga memberi motivasi kepada bapak/ibu guru dan juga anak didik dalam proses berlangsungnya pembelajaran. Hal ini sesuai dengan teori Fungsi penggerak menggambarkan bagaimana seorang manajer mengarahkan dan mempengaruhi bawahan dan bagaimana orang lain melaksanakan tugas yang esensial dalam menciptakan suasana yang menyenangkan untuk bekerjasama. ${ }^{53}$

d. Pengawasan (Controlling)

Pada tahap ini kepala sekolah melakukan pengawasan terhadap kinerja bapak/ibu guru dalam menjalankan amanah yang diberikan oleh kepala sekolah kepada mereka. Adapun dalam proses pengawasan ini kepala sekolah selalu memantau keseharian bapak/ibu guru sejauh mana mereka bisa menjalankan tugas yang sudah diberikan oleh kepala sekolah. Hal ini sesuai dengan teori Pengawasan merupakan suatu kegiatan yang perlu dilakukan oleh setiap pelaksana terutama yang memegang jabatan pimpinan.

Tanpa pengawasan, pimpinan tidak dapat melihat adanya penyimpangan-penyimpangan dari rencana yang telah digariskan dan juga tidak akan dapat menyusun rencana kerja yang lebih baik sebagai hasil dari pengalaman yang lalu. ${ }^{13}$ Sebagai mana yang dilakukan kepala sekolah dalam hal memanajemen memang harus sesuai dengan proses manajemen secara umum mengikuti langkah-langkah merencanakan, mengorganisasikan, memimpin dan mengendalikan. ${ }^{14}$

\section{Faktor Penghambat Dan Faktor Pendukung Dalam Menanamkan Budaya Islami Melalui Pendidikan Model Full Day School Di SD Islam Nabawi Kedungadem}

\footnotetext{
${ }^{11}$ Rohiat, Manajemen Sekolah Teori Dasar dan Praktik (Bandung: Aditama, 2010), 3.

12 Shoimatul Ula. S, Revolusi Belajar (Yogyakarta: Ar-Ruzz Media, 2013), 18-19.

${ }^{13}$ Marno dan Idris, M, Strategi \& Metode Pengajaran: Menciptakan Keterampilan Mengajar yang Efektif dan Edukatif (Yogyakarta: Ar-ruzz Media, 2008), 24.

14 Mulyati, \& Aan Komariah, Manajemen Sekola (Bandung: Pustaka Setia, 2006), 93.
} 
Setiap institusi atau lembaga pasti mempunyai faktor-faktor penghambat maupun faktor-faktor pendukung dalam pelaksanaan kegiatan. Adapun faktor penghambat dan pendukung manajemen kepala sekolah dalam menanamkan budaya Islami melalui pendidikan model full day school di SD Islam Nabawi Kedungadem sebagai berikut:

a. Faktor penghambat dalam menanamkan budaya Islami melalui pendidikan model full day school di SD Islam Nabawi Kedungadem sebagai berikut:

1) Anak didik kurang begitu paham dengan mata pelajaran yang disampaiakan oleh /ibu guru, karena anak didik terkadang melamun dan bermain sendiri saat jam pelajaran berlangsung.

2) /ibu guru kurang disiplin dalam mengajar dan juga terkadang semanagat merka menurun seiring berjalannya waktu.

3) Media pembelajaran yang kurang seperti pengeras suara

b. Faktor pendukung dalam menanamkan budaya Islami melalui pendidikan model full day school di SD Islam Nabawi Kedungadem sebagai berikut:

1) Mendapatkan dukungan dari semua guru dan juga masyarakat sekitar.

2) Pengurus yayasan juga ikut andil dalam mengawasi kinerja guru.

Mayoritas guru yang mendapatkan jadwal mengajar pendidikan Al- Islamiyyah yaitu dari guru yang lulusan pondok pesantren

\section{Kesimpulan}

Berdasarkan hasil penelitian tentang manajemen kepala sekolah dalam menanamkan budaya Islami melalui pendidikan model full day school di SD Islam Nabawi Kedungadem. Baik melalui wawancara, observasi dan dokumentasi, maka dengan demikian peneliti menyimpulkan sebagai berikut:

1. Manajemen yang dilakukan oleh kepala sekolah SD Islam Nabawi Kedungadem dalam menanamkan budaya Islami melalui pendidikan model full day school adalah dengan menggunakan manajemen yang baik serta teratur dimulai dari adanya sebuah perencanaan, pengorganisasian, pelaksanaan serta pengawasan:

a. Perencanaan yang dilakukan oleh kepala sekolah yaitu membuat suatu perencanaan yang sudah terjadwal tentang penyelenggaraan sistem pendidikan dan penanaman budaya Islami yang sesuai dengan visi dan misi sekolah.

b. Pengorganisasian yang dilakukan oleh kepala sekolah yaitu mengoptimalkan dalam memberi tugas para bapak/ibu guru sesuai dengan keahlian mereka, dan tidak membebani mereka dengan merangkap tugas. Khususnya dalam pembelajaran Al-Islamiyyah kepala sekolah memilih guru yang rata-rata lulusan dari pesantren untuk mengajar. Pelaksanaan yang dilakukan oleh kepala sekolah yaitu memberikan jadwal yang harus dijalankan oleh bapak/ibu guru mengenai proses pembelajaran di sekolah mulai dari awal masuk sekolah sampai pelajaran sekolah selesai.

c. Pengawasan yang dilakukan oleh kepala sekolah yaitu mengawasi setiap kinerja bapak/ibu guru dalam menjalankan amanah yang diberikan oleh kepala sekolah kepada mereka.

2. Faktor penghambat dan pendukung manajemen kepala sekolah dalam menanamkan budaya Islami melalui pendidikan model full day school di SD Islam Nabawi Kedungadem:

a. Faktor penghambat dalam menanamkan budaya Islami melalui pendidikan model full day school di SD Islam Nabawi Kedungadem yakni anak didik kurang tangkap dalam memahami mata pelajaran karena terkadang anak didik sering bermain dengan temannya saat jam pelajaran, media pembelajaran yang kurang. Selain itu kedisiplinan guru yang kurang dalam 
mengajar dan semangat yang menurun setelah beberapa minggu setelah rapat yang mengakibatkan proses pembelajaran kurang efektif.

b. Faktor pendukung dalam menanamkan budaya Islami melalui pendidikan model full day school di SD Islam Nabawi Kedungadem sebagai berikut: mendapatkan dukungan dari guru maupun masyarakat sekitar, pengurus yayasan juga ikut andil dalam mengawasi kinerja guru dan guru yang mendapatkan jadwal mengajar Al-Islamiyyah yaitu guru dari pesantren.

\section{Daftar Kepustakaan}

Haryati Diyati, "Peran Kepala Sekolah Dalam Mengembangkan Budaya Sekolah", Tesis, Pasca Sarjana Fakultas Ilmu Pendidikan Universitas Negeri Yogyakarta, Yogyakarta: 2014

Muhaimin. Rekontruksi Pendidikan Islam dari Paradigma Pengembangan, Manajemen Kelembagaan, Kurikulum hingga Strategi Pembelajaran (Jakarta: PT Raja Grafindo Persada, 2009

Rusmin Tumaggor, Kholis Ridho, Nurochim, Ilmu Sosial Dan Budaya Dasar, Ed. 1. Cet. 1 Jakarta: Kencana, 2010

Fatkhul Alim, Wawancara, Bojonegoro, 12 Juli 2020. Pada 08.30-09.30 WIB.

Suharsimi Arikunto, Prosedur Penelitian: Suatu Pendekatan Praktek, Jakarta: PT Rineka Cipta, 2002

Sugiyono, Metode Penelitian Kuantitatif, Kualitatif, Dan R\&D, Bandung: alfabeta, 2017

Nana Syaodah Sukamdinata, Metode Penelitian Pendidikan, Bandung: PT Remaja Rosdakarya, 2008.

Lexy J.Moleong, Metodologi Penelitian Kualitatif, Bandung: PT Remaja Rosdakarya, 2014.

Rohiat, Manajemen Sekolah Teori Dasar dan Praktik, Bandung: Aditama, 2010.

Shoimatul Ula. S, Revolusi Belajar, Yogyakarta: Ar-Ruzz Media, 2013.

Marno dan Idris, M, Strategi \& Metode Pengajaran: Menciptakan Keterampilan Mengajar yang Efektif dan Edukatif, Yogyakarta: Ar-ruzz Media, 2008.

Mulyati, \& Aan Komariah, Manajemen sekola (Bandung: Pustaka Setia, 2006), 93 